\title{
Open Selection of State Civil Apparatus in the Ministry of Administrative and Bureaucratic Reform
}

\author{
Rizki Amalia (Correspondence Author) \\ Institut Pemerintahan Dalam Negeri \\ E-mail: rizkiamalia@ipdn.ac.id
}

Sadu Wasistiono

Institut Pemerintahan Dalam Negeri

Ella Wargadinata

Institut Pemerintahan Dalam Negeri

Rossy Lambelanova

Institut Pemerintahan Dalam Negeri

Received: May 20, 2019 Accepted: June 20, 2019 Online published: July 3, 2019

doi:10.5296/jpag.v9i2.14807ＵRL: https://doi.org/10.5296/jpag.v9i2.14807

\begin{abstract}
Purpose of this research was sought to analyze the open selection of the State Civil Apparatus (ASN) in the Ministry of Administrative And Bureaucratic Reform. It purposes to formulate an open selection model of the State Civil Apparatus (ASN) in the Ministry of Administrative And Bureaucratic Reform. This research used a descriptive research method with a qualitative approach. In order to find a new model or concept of open selection of the State Civil Apparatus (ASN) in the Ministry of Administrative And Bureaucratic Reform, researcher used the Soft System Methodology (SSM) which is a system based approach through the learning process.

The results showed that the open selection of the State Civil Apparatus (ASN) in the Ministry of Administrative And Bureaucratic Reform was good enough, but not yet optimal in the process:(1) Complete Human Resource Planning and Position Analysis,(2) Identify
\end{abstract}


Necessary Knowledge, Skill, and Abilities,(3)Develop Indicators of Required Knowledge, Skill, and Abilities,(4) Construct and Administer Examination(s), (5) Apply Laws and Rules for Certification and Veteran's Preference Points,(6) Make a Selection,(7) Evaluate Performance During Probationary Period. The Ministry of Administrative and Bureaucratic Reform is currently gradually implementing the selection process optimally. Selection process presented by Dresang to be applied to an open selection process in the Ministry of Administrative and Bureaucratic Reform not yet applicable because the principle of "Public Service Neutrality" has not been implemented in Indonesia. Therefore it is necessary to development in the form of a strict separation between the selection process of the selection process is technically and politically, this strict separation is a new driving factor in providing solutions to create an open selection process in the Ministry of Administrative and Bureaucratic Reform to be optimal.

Keywords: State Civil Apparatus (ASN), Open Selection Model, Qualified ASN

\section{Preliminary}

The policy of filling in the High Leadership Position (JPT) through open selection has been widely implemented. The purpose of open selection is to obtain state civil apparatus which have good qualifications, competencies and performance as a condition for occupying certain positions in order to provide the best service to the community. In addition to getting a competent official candidate, open selection is also intended to avoid politicization in filling the positions, so that the results of the implementation of open selection can be based to the right people at the right position rather than on the like or dislike someone. Open selections are made fairly open, objective, transparent, accountable and competitive would avoid corruption practices, collusion and nepotism in occupying certain positions in government organizations. Therefore the government will run well and in accordance with the expectations of society in general.

Through a well-managed and well-performed open selection, it is expected to make a key contribution to the successful achievement of organizational goals. Human resource management play a role in planning and developing strategies, operations and personnel resources to make the dimensions of state civil (ASN) as a key factor that must be considered by top management. All employees in the organization should be given an equal opportunity to grow and develop through a variety of activities that have been programmed.

This is no exception for the Ministry of Administrative and Bureaucratic Reform (Ministry of PANRB) as one of the government organizations that have implemented an open selection system in filling positions. Based on the Regulation of the Ministry of Administrative and Bureaucratic Reform of the Republic of Indonesia Number 3 of 2016 on Organization and Administration of the Ministry of Administrative Reform and Bureaucratic Reform, the Ministry of Administrative And Bureaucratic Reform has the task of conducting its affairs in the utilization of state apparatus and bureaucracy reform to help the President in running the state government.

With regard to the above description, in this case the researcher conducted a study in the 
Ministry of Administrative and Bureaucratic Reform. Ministry of Administrative and Bureaucratic Reform is an institution that became the prototype of the application of bureaucratic reform program. Therefore, in the system of recruitment and coaching staff, had already introduced an open recruitment in mapping and charging high office in the Ministry of Administrative and Bureaucratic Reform, as a form of implementation of Law No. 5 of 2014 On the State Civil Apparatus (ASN).

The selection is open at the Ministry of Administrative and Bureaucratic Reform has been implemented since 2011 to 2018. The Ministry of Administrative and Bureaucratic Reform has carried out five times open selection for the two leadership positions of middle high leader and prime leadership position. In 2011 to 2018 an open selection process conducted by the Ministry of Administrative and Bureaucratic Reform seen a decline in the number of civil servants who participated in the selection process open. In 2015, the number of participants who took part in the selection of the selection Leadership Position High leader of 20 people and has decreased in 2011 when compared to the 28 participants who attended the selection.

The open selection carried out by the Ministry of Administrative And Bureaucratic Reform in 2016 experienced a decrease in the number of civil servants who registered. By 2016 the number of participants who took part in the selection of middle high leader and prime leadership position totaled 118 people consisting of High Leadership Position as many as 51 participants and the Primary High Leadership positions were 67 participants. This number has decreased compared to the year 2012 followed by the selection of 163 participants consisting of High Leadership Position as many as 65 participants and the Primary High Leadership Position with 98 participants. In this study, researchers focused more on the open selection of State Civil Apparatus (ASN) in the middle and high leadership positions carried out in 2016.

From September 8th to 30th, 2016, The Ministry of Administrative And Bureaucratic Reform opened online registration for employees of the State Civil Apparatus (ASN / PNS) to fill some high leadership positions (JPT) the middle and high leadership positions empty through an open selection. The opening of the vacancy announcement number based B/3039/S.PAN-RB / 092 016. For High Leadership Position Associate open 3 (three) JPT: 1). Advisor to the Minister PANRB of Politics and Law, 2). PANRB Advisor to the Minister of Governance and Autonomy, and 3). Advisor to the Minister PANRB Field Work Culture.

Furthermore, to open the Primary High Leadership Position 4 (four) JPT: 1). Assistant Deputy for Administrative and Public Complaints to the Deputy Reforms, Administrative Accountability and Oversight. 2). Deputy Assistant Policy Formulation and Implementation Coordination and Implementation Based Administration Deputy Eleltronik on Institutional and Management. 3). Assistant Deputy Assessment and Coordination Implementation of Institutional Policies and Procedures for Human Development and Culture of the Deputy Institutional and Governance, and 4). Deputy Secretary of Human Resources Apparatus.

The open selection of state civil apparatus at the position of middle high leader and prime leadership position in 2016 experienced twice the extension of open selection registration. Closure of the original registration ends on September 30, 2016 was extended until the 14th 
of October, 2016, then extended until the 27th of October 2016. The occurrence of registration renewal can be seen in the Notification Letter issued by the Ministry of Administrative And Bureaucratic Reform number B/3288/S.PAN-RB/10/2016 on Registration Renewal Leadership Candidate Selection Open High Admiral and Chairman of the Primary in the Ministry of Administrative Reform and Bureaucratic Reform 2016 and the Letter of Announcement No. B/3464/S.PAN-RB/10/2016 on the Second Extension of Registration for Open Selection for High-Level Candidates for Primary and High Leaders at the Ministry of Administrative Reform and Bureaucratic Reform in 2016.

In the implementation of open selection of state civil apparatus in 2016, the results of the selection of paper writing and interview selection have not been completed with the value or score of the selection participants in each announcement letter issued by the Ministry of Administrative And Bureaucratic Reform. The announcement of the selection of paper writing and interview selection is only to convey the names of the participants who passed to follow the next stage alphabetically and the name of the agency participants without specifying the value/score of the participants, it can be seen from the letter of announcement issued by the Ministry of Administrative And Bureaucratic Reform No. B/3841/S.PAN-RB/11/2016 About Writing Papers Results Announcement and the announcement letter No. B/3972/S.PAN-RB/12/2016 On Announcement Selection Interview.

Furthermore, another problem in the open selection is the amount of the assessment center or a certified assessor still limited. Number of assessing agency performance (assessment center) recorded in the Civil Service Agency (BKN) 2016 by 20 institutions and 210 assessor. The amount is very small compared to the needs assessment center to conduct competency test for charging about 30585 Position of Leadership High (JPT) in 34 ministries, 31 Institute of Non-Government (LPNK), 89 non-structural institution (LNS), 34 provincial and 514 district/Municipalities in Indonesia.

In connection with the implementation of open selection carried out by the Ministry of Administrative And Bureaucratic Reform 2016, KASN in 2017 has conducted an evaluation / assessment on the implementation of open selection of state civil apparatus on all local governments and ministries to give the award as a token of appreciation for the commitment and achievement of the performance of government agencies in the application of the merit system in charging JPT through an open selection. Based on data KASN in 2017 of two categories, The Ministry of Administrative And Bureaucratic Reform has not been elected as the recipient of the KASN award in 2017 of the category level of compliance and the quality of governance implementation of open selection and charging JPT Innovation merit in strengthening the implementation of the management system ASN.

The existence of problems that occur in the open selection process in the Ministry of Administrative And Bureaucratic Reform is one of the factors that can cause important phenomena to be examined. Though the preliminary research conducted by Bhasir Azhzhahiri (2012) has stated that "recruitment by open tender in the Ministry of Administrative And Bureaucratic Reform have not really work as expected. Besides the absence of clear regulations on recruitment open bidding, time constraints also remains a big 
challenge for the personnel section of the Ministry of Administrative And Bureaucratic Reform.

Based on the problems described in the background, the problems that will be revealed by the author through this research can be identified as follows: the open selection carried out by the Ministry of Administrative And Bureaucratic Reform in 2016 experienced a decrease in the number of civil servants who registered; the open selection process of state civil apparatus at the position of middle high leader and prime leadership position in 2016 experienced twice the extension of open selection registration; the results of the selection of paper writing and interview selection have not been completed with the value or score of the selection participants in each announcement letter issued by the Ministry of Administrative And Bureaucratic Reform; the limited number of certified assessment centers or assessors; and the Ministry of Administrative And Bureaucratic Reform has not been elected as the recipient of the KASN award in 2017.

In this study, the authors categorize into two (2) formulation of the problem. The second formulation of the problem, namely: how does open selection and open selection model of the State Civil Apparatus (ASN) in the Ministry of Administrative And Bureaucratic Reform?. The purpose of the author conducted research are: To analyze the open selection and to formulate an open selection model of the State Civil Apparatus (ASN) in the Ministry of Administrative And Bureaucratic Reform.

\section{Research Method}

The type of research used in this study is descriptive with a qualitative approach. To find the model or the new concept of open selection State Civil Apparatus (ASN) in the Ministry of Administrative Reform and Bureaucratic Reform, researchers used Systen Soft Methodology (SSM, which is an all-systems thinking approach through a learning process (learning process).

Descriptive qualitative method by Bogdan and Taylor cited Moleong (1998: 2) is defined as "a research procedure that produces descriptive data in the form of words written / spoken of people and behaviors that can be observed". According to Creswell (2014: 4), "a qualitative research methods to explore and understand the meaning by individuals or group of people ascribed social or humanitarian issue".

According Checkland (1990:27), Soft Systen Methodology (SSM) is a "research use thinking systematically involve efforts to explore a variety of issues that have not been structured to be discussed continuously along with stakeholders related institutions to create a model in systems thinking as compared with the real world as a step to solve the problem collectively". How to think the system completely implemented through seven (7) stages as follows: problem considered problematic situation, problem situation Expressed, root definitions of relevant systems of purposeful activity, conceptual models of the system (holons) named in the root definitions, comparison of the model and the real world, changes: culturally desirable systematical feasible and action to improve the problem situation. 


\section{Results and Discussion}

\section{OPEN SELECTION OF STATE CIVIL APPARATUS IN THE MINISTRY OF ADMINISTRATIVE AND BUREAUCRATIC REFORM}

Based on the study above, as for the open selection of state civil apparatus in The Ministry of Administrative And Bureaucratic Reform in real terms in the field, can be explained as follows:

\section{a. Complete Human Resource Planning and Position Analysis}

Complete Human Resource Planning and Position Analysis is complementary human resource planning and analysis of the position/positions. Based on interviews and data, that the process of completing the planning of human resources and analysis of the position has been held by the Ministry of Administrative And Bureaucratic Reform, but is not optimal for the planning of human resources and analysis of the positions is not yet fully complete in accordance with the mandate of Law No. 5 of 2014 on the ASN, which is not yet or not yet made their standards of technical competence.

Completing human resource planning and position analysis can be optimal, if the Ministry of Administrative And Bureaucratic Reform has made technical competency standards in advance as a completeness of the position competency standards at the time of open selection at the pratama and madya leadership 2016. This is in line with the opinion of Ma'ruf (2018: 237), that "the competencies that must be assessed in the JPT candidate competency test are technical competence, managerial competence, and cultural social competence".

Standard of technical competence is important to be made because it can show the level of mastery of a person to a profession or positions ranging from education, technical training functional to the experience of work technically. It is in line with the opinions Kadarisman (2018: 46), "Standards of competence ASN showed levels mastery of a profession or area of responsibility ". The Ministry of Administrative and Bureaucratic Reform is currently gradually working on technical competency standards, this can be known by the issuance of Minister of Administrative and Bureaucratic Reform Regulation number 38 of 2017 concerning State Civil Apparatus Competency Standards. In this regulation, it is strictly regulated regarding the making of job competency standards including technical competency standards.

\section{b. Identify Necessary Knowledge, Skills, and Abilities}

Identify Necessary Knowledge, Skills, and Abilities is to identify the knowledge, skills and abilities necessary. Based on the results, that the process of identifying the knowledge, skills, and abilities required (Identify Necessary Knowledge, Skills, and Abilities) is not optimal to do, because the Ministry of Administrative And Bureaucratic Reform not create a dictionary of technical competence. This second process can be optimized, if the Ministry of Administrative And Bureaucratic Reform have made a dictionary of technical competence prior to the implementation of open selection in 2016 for middle and high leadership positions that have been opened. Preparation of technical competency dictionary is an important thing to do 
because of the presence in the dictionary as a reference about the word or phrase on technical competence. This is in line with the opinions Hoetomo (2005:10).

When associated with the opinion of Hoetomo, the dictionary of technical competence has been made. The Ministry of Administrative and Bureaucratic Reform has a reference list of types of technical competencies, definitions of technical competencies, descriptions of technical competencies and behavioural indicators for each level of technical competence for the position to be selected so that simplify the next stage of the selection process.

The Ministry of Administrative and Bureaucratic Reform is gradually making a dictionary of technical competencies, this can be seen by the issuance of Minister of Administrative and Bureaucratic Reform Regulation number 38 of 2017 concerning the State Civil Service Competency Standards. In this regulation, it is also regulated about making a dictionary of technical competencies.

\section{c. Develop Indicators of Required Knowledge, Skills, and Abilities}

Develop Indicators of Required Knowledge, Skills, and Abilitiesis developing indicators of knowledge, skills and abilities required. Which meant the stage of this process is done the development of indicators of knowledge, skills and abilities required through the question or questions that are made to be used in the implementation of the selection so that it can be a guidance (guidance) for the assessment team (assessors) during questioning at every stage of the test.

Based on interviews and data, that the process of developing indicators of knowledge, skills and abilities needed are carried out by the Ministry of Administrative And Bureaucratic Reform, but not optimal. This is caused by the lack of technical competence test instrument development so as to develop indicators of knowledge, skills and abilities needed is hard to do.

Development of instrument test the technical competence is an important thing to do for the instrument in the implementation of the competency test can be a measuring tool that can be used in the implementation of the selection to see the phenomena observed. This is as stated by Sugiyono (2014: 102), "the instrument is a tool used to measure natural and social phenomena observed.

The Ministry of Administrative and Bureaucratic Reform is currently gradually developing the technical competency test instrument. With the rules regarding job competency standards, indicators can be identified to measure each position competency, namely technical competence, managerial competence and cultural social competence.

\section{d. Devise a Recruitment Plan}

Devise a Recruitment Plan is designing a recruitment plan. Based on the statement, in general can be said that, the process of designing a recruitment plan by the Ministry of Administrative and Bureaucratic Reform has been performing well. It is seen from applicants who apply, either internal and external The Ministry of Administrative And Bureaucratic Reform. It says an internal nature that employees coming from the institution itself within the Ministry of of Administrative And Bureaucratic Reform who participate in implementing the selection 
process, while the externals are employees who enroll are from outside the Ministry of of Administrative And Bureaucratic Reform namely, state civil apparatus in the provinces, cities and counties as well as the state civil apparatus of other ministries.

The number of participants open selection who register in 2016 as many as 118 people for middle and high leadership positions. Of the 118 participants who came from internal ministry of Administrative And Bureaucratic Reform as many as 24 people, and 94 people who came from external ministry of Administrative And Bureaucratic Reform spread from several ministries and regional governments. It can be seen that the ministry of Administrative And Bureaucratic Reform has designed a recruitment plan well. This is indicated by comparison between applicants from the internal PANRB Ministry and those from outside the PANRB Ministry has been proportional, namely from a total of 118 participants, from internal PANRB ministries 24 people. This is inversely proportional to what was conveyed by Berman (2010: 111), "another irony is that although public sector selection is primarily an open application of merit principles, selection for many postions is determined largely by internally based hiring".

\section{e. Screen Applicants for Minimum Qualification}

Screen Applicants for Minimum Qualification is screening applicants for the lowest qualification. The purpose of this process is done the screening of applicants. Applicants who have a minimum qualification can not follow the next test in each phase of the selection process. In other words, applicants who do not qualify in previous qualification, it is no longer opt in later phases at every stage of the selection and be disqualified. While applicants who qualify on a particular stage, the necessary qualifications to follow the next test in the selection process.

From the data available, then get the general picture, that at each stage of an open selection procedure went according upheld, namely knockout at every stage of the test. The Ministry of Administrative And Bureaucratic Reform has implemented the knockout at every stage of the implementation of open selection, ranging from administrative selection process, writing paper, Assessment Center and Interview. For applicants who are in the lowest qualification at each stage of the test, then they are not eligible to participate to the next stage.

In the implementation of administrative selection tests, it can be seen that out of 118 participants who registered for open selection for middle and high leadership positions only 75 people were entitled to proceed to the selection process of making papers. While 43 people were declared not pass the selection or the Applicants have a minimum qualification considered void.

The implementation of selection of paper making, from the selection of 75 participants, 34 people were declared not pass, disqualified and could not continue the interview selection process. Furthermore, there were 41 people who passed the selection on the paper writing test and were entitled to continue in the next selection stage, namely interview selection. Of the 41 people, consisting of 17 middle leader positions and 24 high leader positions.

Then in the exercise of selection interviews, it can be seen that of the 41 people who 
participate in the selection interview remaining three (3) of the participants who passed from the high leadership positions and the middle, thereafter until the end of the announcement of an open selection. While as many as 20 participants interview selection test that otherwise do not qualify and be disqualified.

Based on interviews and data available, it can be seen that the process of screening applicants for the lowest qualification has been conducted by the Ministry of Administrative And Bureaucratic Reform optimal. This is because the Ministry of Administrative And Bureaucratic Reform already firmly enforce the rules knockout for applicants who have a minimum qualification at every stage of an open selection from the selection of administrative, writing papers, and interviews so that they not be acceptable to follow the next test.

Knockout is important in order to reduce the number of participants in the later stages, it is in line with the opinion of Kashmir (2016:102) states, "the knockout, which means that applicants who do not pass at a certain stage can not follow the next stage. This way will reduce the number of participants at later stages."

\section{f. $\quad$ Construct and Administer Examination (s)}

Construct and Administer Examination ( $s$ ) is to develop and administer the exam. The stages in this process is to do a test or tests. The examinations or tests conducted at an open casting call in 2016 for middle and high leadership positions include: Administration Selection, Selection Writing Papers, Assessment Center, and Interview.

Overall in the sixth that phase of the test or exam, the Ministry of Administrative And Bureaucratic Reform already doing quite well, but there are some things that should be improved, namely the lack of public transparency conducted by the Ministry of Administrative And Bureaucratic Reform in each announcement of selection results from the selection of administration, Writing papers, Assessment Center, and Interview. Public transparency in this case is transparency to the announcement of grades or scores on each announcement of results of tests/examinations must be submitted online by attaching test / selection tests in the form of scores/grades. The announcement of the charging JPT selection tests in 2016 have not been equipped with grades or scores obtained ranked by participant selection, but only in alphabetical order the name of the selection participant and the name of the test participant institution.

Public transparency in the open selection of state civil apparatus is important to do given the public is entitled to know the process of recruitment and competence of officials. Public expectations very large community to the candidates, therefore, the selection committee must be transparent, it is in accordance with the opinion of ma'ruf (2018: 79), "because of people's expectations so much to this official figure, the selection committee should be transparent in the open recruitment of this official".

Public transparency in the open selection of state civil apparatus is a must for the selection committee to announce the results of the selection exam and has become the mandate of the Act, This is in line with the views expressed by Ma'ruf (2018: 274), "Based on Government 
Regulation No. 11 of 2017 Article 121 there is requirement for the selection committee to announce the selection results to the public openly ".

The Ministry of Administrative And Bureaucratic Reform has now begun to carry out public transparency in stages, this can be seen in the announcement letter of the open selection result for 2018 paper writing with number B/39/ S.KP.12.00/2018 about the results of paper writing selection, implementation schedule assessment center selection and assessment center stage with letter number B/55/ S.KP.12.00/2018 regarding the results of the open selection assessment selection center for prospective leaders in the Ministry of PANRB. In both letters this announcement has begun to bring up scores in addition to the names and agencies of participants.

\section{g. Apply Laws and Rules for Certification and Veteran's Preference Points}

Apply Laws and Rules for Certification and Veteran's Preference Points is to apply the laws and regulations for certification and experienced person. In the process of implementation of the selection, the selected requirement is the top scorer in each phase of the selection mainly to three (3) participants at the last test in the test execution (certification) is based on the merit system. Determination of the three candidates is still the duty and responsibility of the selection committee.

In the seventh, the stage adopts laws and regulations for certification and experienced people, the Ministry of Administrative And Bureaucratic Reform already works quite well, but not optimal. That is because the lack of implementation of commitment to competence in the implementation of open selection of state civil apparatus. The lack of this commitment can be seen at the time of getting the three candidates with the best grades or scores. Supposed to get three candidates with grades or scores the best, by adhering to a commitment to competence is to integrate all the values of assessors who have averaged based on three dimensions examined, ie managerial competence, technical competence and social competence cultural, It is as delivered by ma'ruf (2018: 261), that "to get the three candidates with the best value, by integrating all grades of assessors who have been averaged. Act No. 5 of 2014 article 69 and Regulation No. 11 of 2017 section 108 states that there are three dimensions of competence that must be tested, namely managerial competence, technical and cultural social ".

Commitment to competence becomes very important in the selection process because of the commitment is an attitude that describes the involvement and shape fidelity someone in the organization, it is in line with the opinions Mowdy in Makmuri (2008: 161), "organizational commitment is an attitude of engagement and form of loyalty someone in an organization. Mowdy, calling the work commitment as the other terms of the commitment of the organization ".

The Ministry of Administrative And Bureaucratic Reform has now begun to implement commitment to job competency in stages, this can be seen from the issuance of regulations on job competency standards which indicate that the Ministry of PANRB has begun to commit to job competency in the implementation of open selection. 
h. Make a Selection

Make a Selection is make a choice. This step is a step in the whole process of being built. In the Act, the PPK (Officer Trustees Personnel) is given the authority to determine the next result that the PPK has the discretion to determine who will be selected later, who had previously been through the recommendation of the Selection Committee Team.

Based on the results, the authors can conclude that the phases of the selection process in making the optimal choice is still not implemented, in because it does not yet verification before leaders make decisions/choices in the form of direct interviews to the participants. Verification becomes important because verification is a process of examination of the truth of reports, statements and others, with the objective of verifying the results observed in accordance with the actual reality exist or occur, it is in line with the opinion of Nasution $(2003 ; 105)$ "verification of the data necessary to prove that the observed results are in accordance with the actual presence or occurrence".

Associated with Nasution's opinion, this verification can be a form of verification candidate biography or a biographical data, whether the data obtained containing the truth so as to give confidence to the head before making a choice/ decision, It is as conveyed by ma'ruf (2018:203) "in addition to situational tests, other measurement techniques can be done by evaluating individual candidates through his bio. The test is to verify biographical information form or bio candidate ".

The Ministry of Administrative And Bureaucratic Reform at this time has begun to gradually verify in the form of direct interviews before making a choice. Verification is carried out by PPK with selection participants.

\section{i. $\quad$ Evaluate Performance During Probationary Period}

Evaluate Performance During Probationary Period is to evaluate the performance during the probation period. Performance is job performance or work quality and quantity achieved by an employee in carrying out the duties and functions in accordance with the responsibilities given to him.

Performance evaluation methods during this trial period is to perform the field orientation or field of study. Indeed the performance assessment carried out not only at the time was the election of the candidate, but it would be nice in the future percobaanpun performance assessment should have been done. The performance assessment can be carried out routinely or periodically at least once a year, if the gains do not meet then given a chance to improve. For the ninth, Kemenpan RB is already carrying out reasonably well, but not optimal. This is because Kemenpan RB has not made the field orientation prior to the candidate who will be elected.

Based on the results, that the process of evaluating the performance during the probation period is not optimal yet implemented, in because not doing orientation or field studies before confirming one person out of three best men. This orientation becomes important so that the candidate can understand the real issues in their respective positions, it conformed to the 
opinion of ma'ruf (2018: 277), "The method used is to assign candidates to carry out field studies in order to understand the real issues The JPT position each for 10 working days ". By studying a comprehensive, factual candidates will get an overview of real conditions in the field so that each candidate can have ample references in terms of strengths, weaknesses, constraints and opportunities that exist according to the vision and mission of the organization.

The Ministry of Administrative And Bureaucratic Reform at this time has begun conducting orientation during the trial period. Orientation is done to the selection participants who pass the selection so that the selection participants get a factual picture before occupying the position that has been applied.

\section{Open Selection Model of State Civil Apparatus in the Ministry of Administrative and Bureaucratic Reform}

The preparation of the conceptual model in this research is done by using the approach of Soft Systems Methodology (SSM). This approach will produce a conceptual model systems of human activity (Human Activity System) that is relevant to an open selection process with the State Civil Apparatus (ASN). This model was developed based on the previous discussion on the process in an open selection process of state civil apparatus. SSM models are produced is the result of duplication of system activities relevant to real-world situations under investigation and is considered problematic.

Comparing in this case is to use a conceptual model that has been created to discuss the problematic real-world situations. This phase is intended not to assess the shortage of problematic situations real world compared to the conceptual model is perfect, but you should always remember that the conceptual model is a tool made based on an angle of view of a purely temporary real world characterized by diverse points of view continues to change both changes slowly or fast. The construction of the model can be seen in the following figure: 


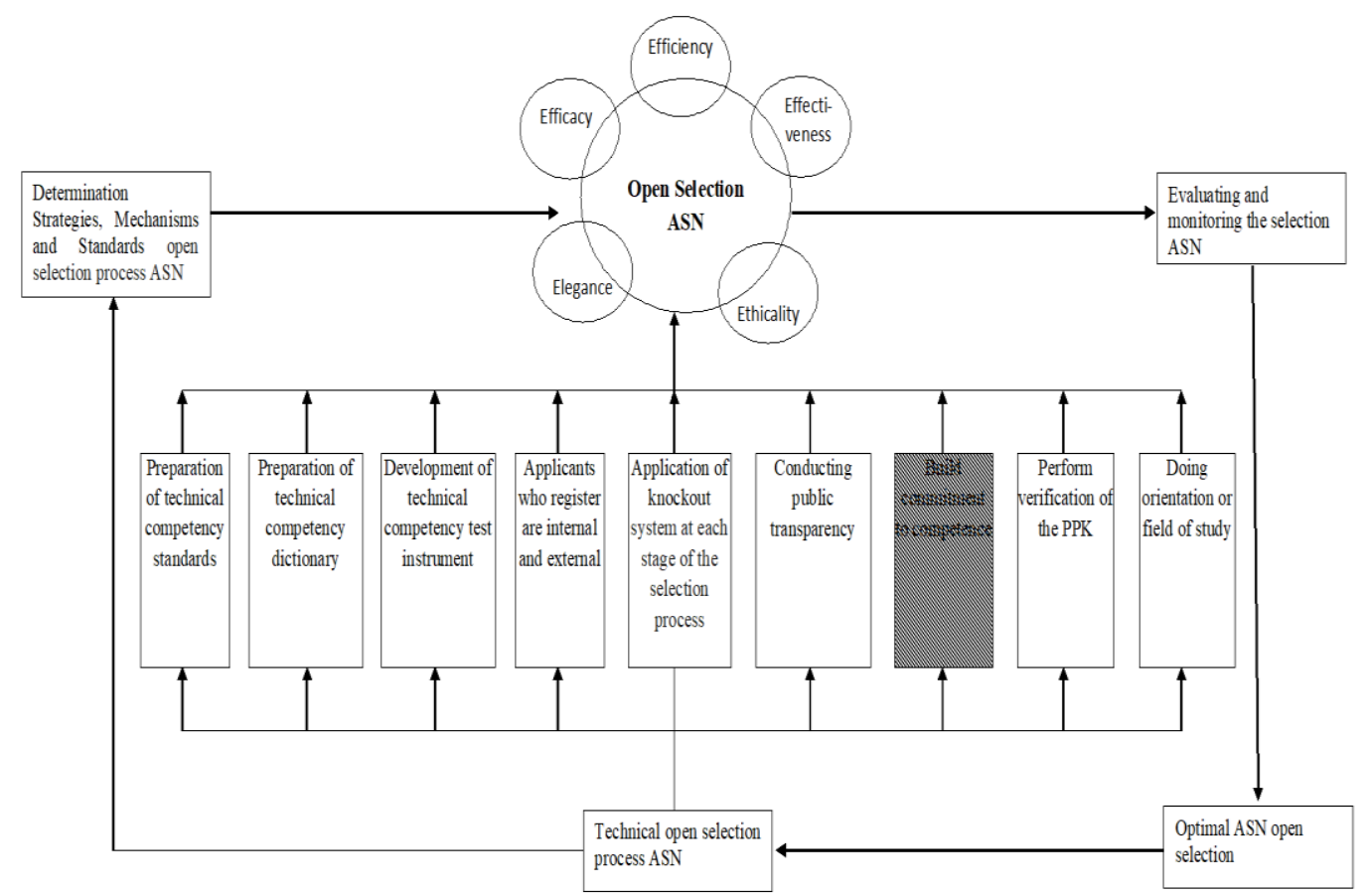

Figure 1. Construction Open Selection Model of State Civil Apparatus in the Ministry of Administrative and Bureaucratic Reform

Source: Research Study, 2019

Based on these, actions to improve, enhance or change the problematic situation in this research is to conduct strict separation between the selection process is technically and politically selection process in an open selection process ASN and make the selection process is politically in a separate assessment / do not join in the technical assessment. Selection process presented by Dresang to be applied to an open selection process in the Ministry of Administrative Reform and Bureaucratic Reform not yet applicable because the principle of "Public Service Neutrality" has not been implemented in Indonesia. Therefore it is necessary to development in the form of a strict separation between the selection process of the selection process is technically and politically, this strict separation is a new driving factor in providing solutions to create an open selection process in the Ministry of Administrative Reform and Bureaucratic Reform to be optimal.

A strict separation between the selection process is technically and politically in the selection process open ASN, in line with the opinions Kadarisman (2018: 50), "The process of recruitment ASN and first-aid carried out openly, prioritizing skills and abilities, and should not be based on political affiliation". Open selection of state civil apparatus in the Ministry of Administrative and Bureaucratic Reform can run optimally when considering technical evaluation and monitoring of the open ASN selection process and the selection process is open politically. The process can be carried out through the establishment of strategies, mechanisms and standards for the ASN open selection process. In the process include: Efficacy, Efficiency, Effectiveness, Ethicality, and Elegance. In more detail can be seen in the following figure: 


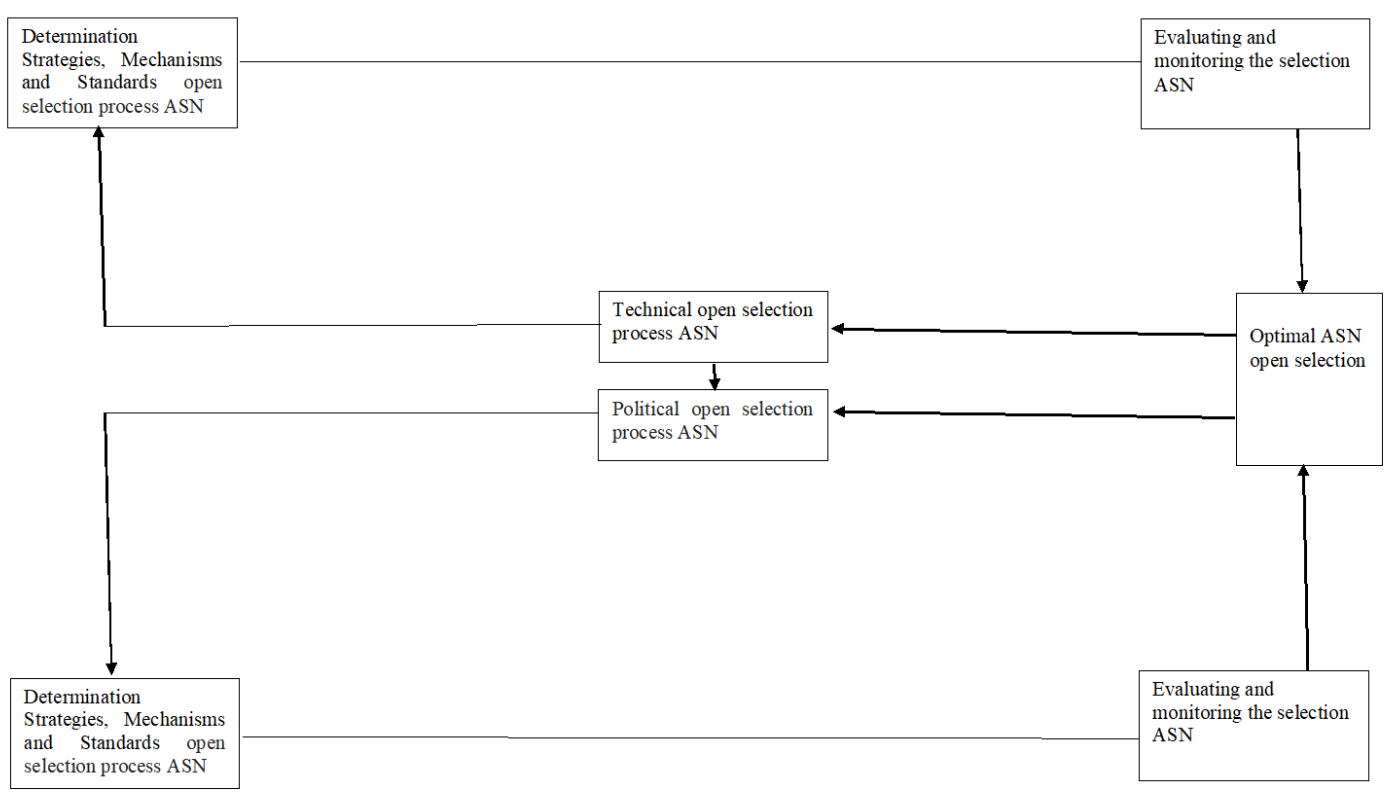

Figure 2. Open Selection Model of State Civil Apparatus in the Ministry of Administrative and Bureaucratic Reform

Source: Research Study, 2019

\section{Closing}

Open Selection process of State Civil Apparatus in the Ministry of Administrative Reform and Bureaucratic Reform at position of middle high leader and prime leadership position in 2016 was good enough, but not yet optimal. This can be seen in the process: (1) Complete Human Resource Planning and Position Analysis, (2) Identify Necessary Knowledge, Skills, and Abilities, (3) Develop Indicators of Required Knowledge, Skills, and Abilities, (4) Construct and Administer Examination (s), (5) Apply Laws and Rules for Certification and Veteran's Preference Points, (6) Make a Selection, (7) Evaluate Performance During Probationary Period. The Ministry of Administrative and Bureaucratic Reform is currently gradually implementing the selection process optimally. Selection process presented by Dresang to be applied to an open selection process in the Ministry of Administrative and Bureaucratic Reform not yet applicable because the principle of "Public Service Neutrality" has not been implemented in Indonesia. Therefore it is necessary to development in the form of a strict separation between the selection process of the selection process is technically and politically, this strict separation is a new driving factor in providing solutions to create an open selection process in the Ministry of Administrative and Bureaucratic Reform to be optimal. Open selection model of state civil apparatus in the implementation of the selection process needs to be a picture in the implementation of open selection upcoming. Program open selection of state civil apparatus is one part of the action plan 9 (Nine) acceleration program Reforms in the system of promotion of civil servants openly. 


\section{Macrothink}

Journal of Public Administration and Governance

ISSN 2161-7104 2019, Vol. 9, No. 2

\section{Reference}

Azhzhahiri, B. (2012). Recruitment Through Open Bidding Announcement Analysis in the Selection of Prospective Echelon II. International Journal of Administrative Science \& Organization, Volume 19, Number 3, September 2012, ISSN 0854-3844, Accredited by the Higher Education Ministry of National Decree No: 64a / DIKTI / Kep / 2010.

Berman, E. M. (2010). Human Resources Management in Public Service: Paradoxes, Process, and Problems. Sage Publications, Inc.

Checkland, P. B., \& Scholes, J. (1990). Soft Systems Methodology in Action. John Wiley \& Sons: Chichester.

Creswell, J. W. (2014). Research Design Approach Qualitative, Quantitative and Mixed (translation), Yogyakarta: Reader Student.

Dresang, D. L. (2002). Public Personnel Management and Public Policy, Fourth Edition, Logman Publishers.

Hoetomo. (2005). Kamus Lengkap Bahasa Indonesia (Complete Dictionary Indonesian). Surabaya: Student Partner.

Kadarisman, M. (2018). Manajemen Aparatur Sipil Negara (Management of the State Civil Apparatus). Depok: PT RajaGrafindo Persada.

Kasmir. (2016). Manajemen Sumber Daya Manusia, Teori dan Praktik (Human Resource Management, Theory and Practice). Jakarta: PT. Raja Grafindo Persada.

Makmuri, M. (2008). Perilaku Organisasi (edisi revisi) (Organizational Behavior (revised edition). Yogyakarta: Gadjah Mada University Press.

Ma'ruf, J. J. (2018). Assessment Center, Pedoman Uji Kompetensi Jabatan Pimpinan Tinggi (Assessment Center, Manual High Leadership Position Competency Test). Jakarta: PT. Gramedia Pustaka Utama.

Moleong. (1998). Metodologi Penelitian Kualitatif (Qualitative Research Methodology). Bandung: Youth Rosdakarya.

Nasution. (2003). Metode Penelitian Naturalistik Kualitatif (Naturalistic Qualitative Research Methods). Bandung: Tarsito.

Sugiyono. (2014). Metode Penelitian Kuantitatif dan Kualitatif dan R\&D (Quantitative and Qualitative Research Methods and $R \&$ D). Bandung: Alfabeta.

\section{Copyright Disclaimer}

Copyright for this article is retained by the author(s), with first publication rights granted to the journal.

This is an open-access article distributed under the terms and conditions of the Creative Commons Attribution license (http://creativecommons.org/licenses/by/4.0/). 